\title{
ROSA DE SOMBRA
}

Pollyanna Furtado é mestra em Letras - Estudos Literários pela Universidade Federal do Amazonas e professora de Literatura Brasileira na UNINORTE. É autora do livro de poemas Simetria do Caos, editora 7 Letras, 2011.

E-mail: pollyannafurtado@yahoo.com.br

No vermelho da sombra, esconde-se uma rosa azul.

Rosa precária e triste.

Sem pétalas nem odor.

Aquela coisa fria,

que se encontra

ao pé da porta,

de talos inacabados,

é sombra, coisa morta.

Eu vi uma rosa rude

se fechar na boca da noite.

Sem tilintar de sinos,

rosa venosa

de Vênus

venenosa.

Matéria lendária de sonho.

Um vulto apenas na manhã.

Nem um pássaro quis beijá-la.

A rosa se desfez. 